\title{
The Accuracy of Federal Academic Library Statistics
}

\author{
BY ELI M. OBOLER
}

AMERICAN ACADEMIC LIBRARIANS were overjoyed to receive the annual (196263 ) compilation of academic statistics so early (February) and yet including so high a percentage ( 70 per cent) of the institutions surveyed. ${ }^{1}$ A closer examination of the figures revealed, however, certain imperfections and misleading inclusions and omissions that deserve some attention and analysis. This is not a criticism of the Library Services Division, but rather of a great many of the respondents.

The figures given for "volumes" and for "volumes added," especially in relation to expenditures indicated for "books and other library materials," should cause particular concern. There are, to say the least, many rather odd figures here. For example, one library, without any footnote explanation, suddenly increased from less than twenty-five thousand volumes added during 1961-62 to more than three times that number, while the amount shown for "books and other library materials" only increased approximately 50 per cent. Upon inquiry, the librarian of this institution stated that "from storage in one attic we removed forty thousand items, some of which have been cataloged, but in the main we are as yet unsure of the number which will be added. The addition of a large number of volumes also included about one-fourth public documents, state and federal, and almost fifty thousand volumes in microtext." The preceding year neither of these items had been counted, but somehow, in this and other academic libraries, 1962-

${ }^{1}$ Increased to 90 per cent in June, with the ALALAD published supplement. All figures herein are based on the original document.
Mr. Oboler is University Librarian, Idaho State University, Pocatello.

63 became a great year for including microtexts in "volumes added during the year" and "number of volumes at end of the year."

As a matter of fact, although this particular institution did not bother to state publicly that microtexts were included for the first time, five institutions did so state. Interestingly enough, at the same time thirteen academic institutions included a footnote stating that their figure for 1962 63 "excludes microprints, microcards, microfilms, and other forms of microtext." Just what valid comparisons may be drawn from such utterly different figures is puzzling.

The farther one goes into this labyrinth or wonderland of academic statistics, the "curiouser and curiouser" they get. Under "number of volumes at end of year," only three institutions indicated "estimated" in a footnote. Yet eighty-nine others had figures for this item ending in round numbers. It would take considerable statistical coincidence for so many libraries to come to the end of one particular year with exactly " 50,000 " or " 10,000 " or similarly obviously rounded-off figures. Yet they did not admit that their count was estimated; therefore, such figures go in to be compared with the data given by those who have kept very strict count. Upon examination of these eighty-nine institutional reports, one finds that in 1961-62 forty-eight gave rounded-off figures.

The above phenomena merely give 
grounds for speculation, but one could draw rather definite conclusions from institutions which, when asked specifically, as the questionnaire did, for "number of volumes added during fiscal year (report actual number of volumes acquired, DO NOT subtract volumes withdrawn)" went ahead and gave "net" figures. How would it have been possible for such institutions to have determined net figures without first having the gross figures? Since they had the gross figures, why did they not give them as requested in the questionnaire?

Further examination is also revealing. Included in the footnotes were various explanations referring to the specific data on "number of volumes at end of year" and "number of volumes added during year." One footnote stated, "excludes microprints . . ." as cited above. Some stated, "an estimated figure"; some stated, "excludes bound periodicals," although the definition of volumes given on page one of the questionnaire stated clearly that "a volume is any printed, typewritten, mimeographed, or processed work, bound or unbound, that has been cataloged or fully prepared for use. Includes microcards, microfilms, microprints, and other forms of microtext." Some stated, "excludes government documents." Some stated, "change in fiscal year on a calendar basis; the number of volumes added is for eighteen-month period." Some stated, "includes only fully cataloged and processed books and periodicals," which sounds like another way of saying "excludes microtext," but could mean any one of a number of things. One said, "includes data for high school library." Is this a useful statistic for comparative purposes within academic circles? One said, "excludes microfilms and recordings; includes 150,000 microcards." This same institution indicated a little over 150,000 volumes in 1961-62 and over 400,000 for $1962-63$. One footnote, which is used by several institutions, stated, "excludes government documents."
The instructions on page one of the questionnaire are not clear. The key phrase here is "fully prepared for use." Is a government document that has been assigned any kind of a classification number arranged any particular way so that it can readily be found and circulated "fully prepared for use?" Different libraries, obviously, differ on this. One library states in a footnote that its listing of "number of volumes at end of year" includes "government serials."

This all seems to indicate the necessity for clarification by definition of what is wanted by the United States Office of Education and by the library profession; a better understanding of what is being asked for is needed by those who fill in the questionnaires. Furthermore, the Office of Education should probably print only those statistics that make sense.

For example, does it make sense to print a particular figure for one year in a category such as "number of volumes at end of year," and a figure next to it of "number of volumes added during year" that could not be compatible? Here are a few examples of such incompatibility.

One institution, in 1961-62, had fewer than fifty thousand volumes. It indicates five thousand volumes added during year, and then shows one hundred thousand volumes at the end of 1962-63! Another showed sixty thousand volumes at the end of 1961-62, an addition of nine thousand volumes during this past year, and then claims over one hundred thirty thousand for "number of volumes at end of year" 1962-63. Still another shows less than ninety thousand last year, additions of less than seven thousand, and total volumes now of almost one hundred thirty thousand. This is remarkable arithmetic!

Another school's holdings went from a little over seventy thousand last year to over one hundred thousand this year, with "number of volumes added during year" being indicated as under five thou- 
sand. How can one add under five thousand to just over seventy thousand and come up with a total of over one hundred thousand? Such figures as these should not be included in a compilation of comparative data. At least, such figures should have been indicated as "estimated." One of the most interesting examples of arithmetic found was of a school that had under twenty-five thousand books in 196162 , claimed gains of well under a thousand, and then showed the number of volumes at end of year at over thirty-five thousand!

Correspondence with college librarians leads to the conclusion that the pressure to "keep up with the Joneses" has become, in many instances, so considerable that academic librarians have simply put down figures that look nice rather than accurate figures. ${ }^{2}$

It is to be hoped that the studies now in process under the auspices of the Council on Library Resources, aimed to standardize library statistics, will be successful. At least, academic librarians should be aware of what they are doing, and the Office of Education should be aware of what it is doing. Putting together indiscriminate statistics into what look like highly organized charts and tables will still produce results and figures which are misleading and inaccurate. What good is the so-called analytic report, if the statistics it analyzes are disparate and dissimilar?

\footnotetext{
${ }^{2}$ The state university library supervised by this writer has well over three hundred thousand government documents. These are not included in the totals reported to the federal government, because such publications, although they are kept in bureau order and within each bureau by type of publication and then numerically, are not considered by us as being "fully ready for use" in terms of the government definition. Those few documents in the writer's library which will get better use if they are fully cataloged and specified and placed among the books in the regular collection are included in the totals, but no others; nor, in this library, have microtexts in any form been included in final reported totals, mainly because of the confusion as to how they are to be counted.
}

William H. Carlson, director of libraries of the Oregon State University, recently said that "figures appearing in such statements [referring to statements as the ones issued by the Office of Education and the Association of Research Libraries] are very rough and sometimes, in a comparative sense, even misleading evidence of comparative strength. Sometimes, too, the figures used become suspect. Over decades and centuries the process of adding annual accretions to the accumulated base, and withdrawing the worn out, the lost, and the obsolescent may get badly out of gear. . . . Common-sense observation also indicates that sometimes, either knowingly or unknowingly, figures used have become padded."3

Federal academic library statistics as now presented are undoubtedly accurate reports of replies to questionnaires, but a great many of the individual items presented are inconsistent or obviously fallacious. No matter how precise and clear the questions asked may be, academic librarians must still rely on the accuracy of replies. And no one can examine the 1962-63 figures, especially in relation to previous data, without strong misgivings as to their usefulness for comparative purposes because of the many distortions and inaccuracies they contain.

Action on a nationwide scale toward achieving the obviously impossiblecomplete and accurate figures on the holdings of all academic libraries-is imperative. Each college or university head librarian perhaps has the professional obligation to make a physical inventory of his library's holdings at least once each five years; he certainly should provide accurate statistics yearly to the Office of Education.

\footnotetext{
3 "The Field Headquarters of the Mind: Measures of Library Excellence," Improving College and Uni-
} versity Teaching, XII (Spring 1964), 68-69. 